\title{
THE INTERACTIVE EFFECTS OF PHOSPHORUS AND SALT ON GROWTH, WATER POTENTIAL AND PHOSPHORUS UPTAKE IN GREEN BEANS
}

\author{
GULMEZOGLU, N. ${ }^{*}-$ DAGHAN, $\mathrm{H}$. \\ Eskişehir Osmangazi University, Agricultural Faculty, Department of Soil Science and Plant \\ Nutrition, 26160 Eskişehir, Turkey \\ (phone: +90-222-324-2991; fax: +90-222-324-2990) \\ *Corresponding author \\ e-mail:dgulmez@ogu.edu.tr \\ (Received $7^{\text {th }}$ Apr 2017; accepted $2^{\text {nd }}$ Jun 2017)
}

\begin{abstract}
The salt tolerance of crop species and cultivars may vary depending on the mineral content of the soil. Phosphorus $(\mathrm{P})$ availability and uptake is limited in calcareous soil. The main problem of salinity and $\mathrm{P}$ deficiency is reduced yield in arid and semiarid regions. To examine the relations between $\mathrm{NaCl}-$ salinity $(0,50 \mathrm{mM}, 100 \mathrm{mM}$ and $150 \mathrm{~mm})$ and $\mathrm{P}\left(0,30,60\right.$ and $90 \mathrm{~kg} \mathrm{P}_{2} \mathrm{O}_{5}$ ha ${ }^{-1}$ stated $\mathrm{P}_{0}, \mathrm{P}_{30}, \mathrm{P}_{60}$ and $\mathrm{P}_{90}$, respectively) on growth, water potential, chlorophyll and $\mathrm{P}$ concentration of green beans, a pot experiment was conducted for thirty days in a climate chamber. The experiment was designed as a complete randomized block with three replicates. Salinity decreased dry matter and P concentrations of root, stem and leaf as well as the chlorophyll content of old leaves, while $\mathrm{P}$ application increased dry weight and the $\mathrm{P}$ concentration of plants. Chlorophyll content of young leaves was increased by $\mathrm{P}$ application and $\mathrm{P}_{60}$ with $50 \mathrm{mM}$ application led to a reduction of water loss in turgor when compared to control. The results of this study suggested that dry weight and $\mathrm{P}$ concentration in green bean leaves were affected positively by $\mathrm{P}_{60}$ together with $50 \mathrm{mM} \mathrm{NaCl}$ application. In addition, the same application decreased the loss of turgidity of younger leaves. The adequate $\mathrm{P}$ application may have contributed to the water potential of green beans under salinization.
\end{abstract}

Keywords: salinity, Phaseolus vulgaris L., chlorophyll, root:shoot ratio, turgidity

\section{Introduction}

Soil salinity is increasing in many parts of the world and is a serious environmental problem facing mankind. It has been estimated that about more than $50 \%$ of the arable land could be salinized by the year 2050 (Jamil et al., 2011). Salt stress prevents the growth and development of the plants due to osmotic and ion stress (Parida and Das, 2005; Kachout et al., 2009). In the root rhizosphere, osmotic stress occurs first with the increasing salt amount (Tuteja, 2007). Decreases in the usable water amount causes cell expansion to diminish as well as a sprout development to slow down, reducing the ability of plants to absorb essential nutrients (Dadkhah and Grrifiths, 2006).

Phosphorus $(\mathrm{P})$ is the second essential macronutrient in soils after nitrogen $(\mathrm{N})$ that plays an important role in plant growth. It is involved in many physico-chemical reactions in plants such as energy transfer, photosynthesis, respiration, nutrient movement within the plant, and transfer of genetic characteristics in plants. In additions, $\mathrm{P}$ is also a contributory factor in promoting early root formation and growth, increasing water-use efficiency, and plant maturity, rooting, and flowering and improves the quality of crops (Johnston and Steén, 2000; Rafat and Sharifi, 2015). The availability of $\mathrm{P}$ in soil depends on soil properties such as $\mathrm{pH}$, lime, texture, main material, salinity, etc. Salinity and $\mathrm{P}$ deficiency together affect negatively plant growth and crop productions in arid and semi-arid areas with calcareous soils (Bargaz et al., 2016). 
Phosphorus deficiency is perhaps the most limiting factor for symbiotic N-fixation, resulting from an association with rhizobial bacteria and leading to decrease in productivity of legume crops (Kouas et al., 2005).

The common bean (Phaseolus vulgaris L.) is widely grown around the world and it is one of the most important nutritious crops as both green and dry, for direct human consumption. In general, common bean production in legumes ranks first in the world according to FAOStat (2013). The research is limited about the effect of P application on green bean plant growth under salinity stress. The objective of this study was to investigate the interaction between $\mathrm{P}$ and $\mathrm{NaCl}$ and both treatments' effects on growth, chlorophyll content, water potential, chlorophyll, and $\mathrm{P}$ uptake in the green beans.

\section{Material and Methods}

\section{Experimental setup}

Mostly grown for early maturing, the green bean 'Kirk gunluk' was used in a pot experiment conducted in a climate chamber. The physical and chemical properties of the pot soil were determined. The texture analysis of the soils was done according to the Bouyoucos hydrometer method (Bouyoucos, 1962). The $\mathrm{pH}$ and EC were measured in a 1:2.5 soil:water extract. Walkley and Black's rapid titration method (Nelson and Sommers, 1996) was used for the estimation of organic matter contents of the soils. The available P was determined according to Olsen et al. (1954). Potassium concentration was defined by the method of $1.0 \mathrm{~N}$ ammonium acetate extraction (Richards, 1954). The soil was extracted with DTPA at pH 7.3 (Lindsay and Norvell, 1978), and bioavailable $\mathrm{Fe}, \mathrm{Cu}, \mathrm{Mn}$, and $\mathrm{Zn}$ concentrations were determined using an atomic absorption spectrometer (Analytik Jena novAA 350, Jena, Germany). The experimental soil was slightly alkaline $(\mathrm{pH} 7.66)$ and non-saline $\left(1.2 \mathrm{dS} \mathrm{m}^{-1}\right)$; it also consisted of a loam texture, moderate $\mathrm{CaCO}_{3}(11.83 \%)$, very low organic matter $(0.69 \%)$, low K (136 mg $\left.\mathrm{kg}^{-1}\right)$, very low $\mathrm{P}\left(0.85 \mathrm{mg} \mathrm{kg}^{-1}\right)$, sufficient $\mathrm{Cu}\left(1.1 \mathrm{mg} \mathrm{kg}^{-1}\right)$, very low $\mathrm{Mn}\left(0.89 \mathrm{mg} \mathrm{kg}^{-1}\right)$, low $\mathrm{Zn}\left(0.23 \mathrm{mg} \mathrm{kg}^{-1}\right)$, and low Fe $\left(1.2 \mathrm{mg} \mathrm{kg}^{-1}\right)$.

A basal treatment of $200 \mathrm{mg} \mathrm{N} \mathrm{kg}{ }^{-1}$ soil as $\left(\mathrm{NH}_{4}\right)_{2} \mathrm{SO}_{4}, 250 \mathrm{mg} \mathrm{K} \mathrm{kg}{ }^{-1}$ soil as $\mathrm{K}_{2} \mathrm{SO}_{4}$, $5 \mathrm{mg} \mathrm{Zn} \mathrm{kg}^{-1}$ soil as $\mathrm{ZnSO}_{4} .7 \mathrm{H}_{2} \mathrm{O}$, and $2.5 \mathrm{mg} \mathrm{Fe} \mathrm{kg}^{-1}$ soil as Fe-EDTA was applied to each pot, which was filled with $2000 \mathrm{~g}$ of air-dried soil. Phosphorus rates were set to be $\mathrm{P}_{2} \mathrm{O}_{5}$ as 0 ( $\mathrm{P}_{0}$ as a control), $30 \mathrm{~kg} \mathrm{ha}^{-1}\left(\mathrm{P}_{30} ; 7-9 \mathrm{mg} \mathrm{P} \mathrm{kg}^{-1}\right.$ as low $), 60 \mathrm{ha}^{-1}\left(\mathrm{P}_{60} ; 15-20 \mathrm{mg}\right.$ $\mathrm{P} \mathrm{kg}^{-1}$ as medium), and $90 \mathrm{~kg} \mathrm{ha}^{-1}\left(\mathrm{P}_{90} ; 30-35 \mathrm{mg} \mathrm{P} \mathrm{kg}\right.$ as high), calculated for each pot and applied from a triple superphosphate $\left(43 \% \mathrm{P}_{2} \mathrm{O}_{5}\right)$. The experiment was designed as a complete randomized block with three replicates.

Green bean plants were grown under controlled conditions (16 h light period (light intensity of $7000 \mathrm{Lux}$ ) at $26 / 18^{\circ} \mathrm{C}$ light/dark temperature cycle, and $60-70 \%$ relative humidity) in a climate chamber. The seeds were sown in a seed plot $(31.5 \times 51.5 \mathrm{~cm})$ filled with a mixture of soil:perlite (3:1), and plants were grown five or six days until they germinated. After that, 10 of the selected seedlings were transferred to each pot. Plants were irrigated with $50 \mathrm{ml}$ of deionized water daily until the fully developed true leaf at the third node (V1) emerged. After this stage, a salt treatment by irrigation with $\mathrm{NaCl}$ solutions of 50,100, and $150 \mathrm{mM}$ was applied for two weeks duration. 


\section{Loss of turgidity leaf (LT) measurement}

To obtain the turgid weight, $1.5 \mathrm{~cm}$ discs from old and young leaves were taken from each pot. Firstly, the fresh weight (FW) of the samples was determined and then the samples were floated on distilled water in a petri dish for $24 \mathrm{~h}$ at room temperature. Next, the leaf discs were removed from the petri dish, the surface had blotted, and then were weighed immediately for turgid weight (TW) (Barrs and Weatherley, 1962). The loss of turgidity (LT) was calculated as follows: LT $(\%)=[(\mathrm{TW}-\mathrm{FW}) / \mathrm{TW}] \times 100$.

\section{Relative water content measurement}

The leaf relative water content (LRWC, \%) was calculated based on methods from Yamasaki and Dillenburg (1999). Disc samples $0.5 \mathrm{~cm}$ in diameter were taken from old and young leaves was taken from each pot at harvest time. After FW was measured, the leaf discs were floated in distilled water in a closed petri dish. After $24 \mathrm{~h}$, the leaf surface water of samples was wiped with tissue paper and weighed (TW). At the end of the turgid period, leaf samples were placed in a pre-heated oven at $65^{\circ} \mathrm{C}$ for $48 \mathrm{~h}$, in order to obtain the dry weight (DW). All DW values were determined using an analytical scale, with precision of $0.001 \mathrm{~g}$. Measurements of FW, TW, and DW were used to calculate LRWC using the equation as follows: LRWC $(\%)=[(\mathrm{FW}-\mathrm{DW}) /(\mathrm{TW}-$ DW)] x 100 .

\section{Chlorophyll determination}

The younger and older leaf chlorophyll contents were measured with a chlorophyll meter (Konica-Minolta SPAD-502) as a SPAD unit before harvest.

\section{Determination of dry matter and phosphorus concentration}

Plants were harvested as a leaf, stem, and root parts 30 days after sowing and then rinsed in deionized water. All plant samples were dried at $70^{\circ} \mathrm{C}$ for $48 \mathrm{~h}$ and weighed to determine dry matter production. The root to shoot (stem with leaves) dry weight ratio was also calculated.

The dry plant samples were ground with a ball mill (Retsch MM-301). The $0.2 \mathrm{~g}$ ground samples were digested with $2 \mathrm{ml} \mathrm{H}_{2} \mathrm{O}_{2}$ and $5 \mathrm{ml} \mathrm{HNO}_{3}$ in a microwave (CemMARSXpress 6) oven. Phosphorus was determined by spectrophotometry (Thermo Aquamete-2000E), according to Barton (1948). Certified reference material (tomato leaf samples, National Institute of Standards and Technology, Gaithersburg, MD, USA) was also used in order to check the accuracy of the digesting and measuring methods of $\mathrm{P}$ concentrations used in the study.

\section{Statistical analysis}

Data were analyzed for variance using the IBM SPSS Statistics 20.0 program, and mean separation was accomplished using the least significant difference (LSD) test at $p$ $\leq 0.05$. The data presented are mean values obtained from three independent replications. 


\section{Results and Discussion}

\section{Plant growth}

The influence of $\mathrm{P}$ and $\mathrm{NaCl}$ applications on dry matters, root/shoot $(\mathrm{R} / \mathrm{S})$ ratios and $\mathrm{P}$ concentrations of the green beans is shown in Table 1 and Figure 1. The interaction of $\mathrm{P}$ x Salinity (S) with increasing $\mathrm{P}$ and $\mathrm{NaCl}$ application on the root and the leaf dry weight of the bean cultivar was significant, while stem dry weight was affected by $\mathrm{P}$ and $S$ ( $p<0.05$ and 0.01 , respectively). Root, stem, and leaf dry matters were increased with $\mathrm{P}$ application. The leaf dry weights were higher than the stem and root weight, and root dry weight followed leaf dry weight (Table 1; Figure 1). The $\mathrm{P}_{30}, \mathrm{P}_{60}$, and $\mathrm{P}_{90}$ applications on leaf $(11 \%, 14 \%$, and 19\%, respectively), stem $(10 \%, 19 \%$, and 19\%, respectively) and root dry weight (7\%, 9\%, and $13 \%$, respectively) were increased when compared to control plants. These results were consistent with Fageria and De Carvalho (1996), Adhami and Ronaghi (1999), and Gidago et al. (2011), who stated that the dry weight of biomass would be increased with increasing P doses. It is known that leaf development depends on a high degree of $\mathrm{P}$ concentration in the tissue because $\mathrm{P}$ plays an important role in the synthesis of sucrose and starch in photosynthesis, which increases plant dry weight (Cakmak et al., 1994).

Table 1. The effects of $\mathrm{P}$ and $\mathrm{NaCl}$ treatments on dry weight and $\mathrm{P}$ concentration of green bean

\begin{tabular}{|c|c|c|c|c|c|c|c|}
\hline \multirow{2}{*}{ Treatments } & \multicolumn{3}{|c|}{ Dry Weight (g plant $\left.{ }^{-1}\right)$} & \multirow{2}{*}{$\mathrm{R} / \mathrm{S}$} & \multicolumn{3}{|c|}{ P Concentration (\%) } \\
\hline & Root & Stem & Leaf & & Root & Stem & Leaf \\
\hline $\mathrm{P}_{0}$ & $0.334 \mathrm{c}$ & $0.236 \mathrm{~b}$ & $0.686 \mathrm{~b}$ & 0.363 & $0.366 \mathrm{~b}$ & $0.170 \mathrm{c}$ & $0.209 \mathrm{~b}$ \\
\hline $\mathrm{P}_{30}$ & $0.356 a b$ & $0.259 \mathrm{ab}$ & $0.762 \mathrm{a}$ & 0.350 & $0.375 b$ & $0.172 \mathrm{c}$ & $0.233 \mathrm{a}$ \\
\hline $\mathrm{P}_{60}$ & $0.365 \mathrm{ab}$ & $0.280 \mathrm{a}$ & $0.783 \mathrm{a}$ & 0.342 & $0.379 \mathrm{ab}$ & $0.184 b$ & $0.242 \mathrm{a}$ \\
\hline $\mathrm{P}_{90}$ & $0.379 \mathrm{a}$ & $0.281 \mathrm{a}$ & $0.816 \mathrm{a}$ & 0.349 & $0.397 \mathrm{a}$ & $0.203 \mathrm{a}$ & $0.248 \mathrm{a}$ \\
\hline$L S D_{0.05}$ & 0.032 & 0.039 & 0.063 & 0.040 & 0.019 & 0.010 & 0.022 \\
\hline $\mathrm{S}_{0}$ & $0.441 \mathrm{a}$ & $0.313 \mathrm{a}$ & $0.838 \mathrm{a}$ & $0.385 \mathrm{a}$ & $0.378 \mathrm{ab}$ & $0.161 \mathrm{c}$ & $0.230 \mathrm{~b}$ \\
\hline $\mathrm{S}_{50}$ & $0.338 b$ & $0.241 b$ & $0.792 \mathrm{ab}$ & $0.329 b$ & $0.384 \mathrm{a}$ & $0.198 \mathrm{a}$ & $0.269 \mathrm{a}$ \\
\hline$S_{100}$ & $0.333 b$ & $0.255 \mathrm{ab}$ & $0.763 b$ & $0.330 \mathrm{~b}$ & $0.392 \mathrm{a}$ & $0.189 \mathrm{ab}$ & $0.224 b$ \\
\hline $\mathrm{S}_{150}$ & $0.321 b$ & $0.247 \mathrm{~b}$ & $0.654 \mathrm{c}$ & $0.360 \mathrm{ab}$ & $0.361 \mathrm{~b}$ & $0.182 \mathrm{~b}$ & $0.209 \mathrm{~b}$ \\
\hline$L S D_{0.05}$ & 0.032 & 0.039 & 0.063 & 0.040 & 0.019 & 0.010 & 0.022 \\
\hline$P$ & $*$ & $*$ & $* *$ & $\mathrm{~ns}$ & $*$ & ** & ** \\
\hline$S$ & $* *$ & $* *$ & $* *$ & $*$ & $*$ & $* *$ & $* *$ \\
\hline$P \times S$ & $*$ & ns & $* *$ & $\mathrm{~ns}$ & $\mathrm{~ns}$ & $\mathrm{~ns}$ & $*$ \\
\hline
\end{tabular}

*, **: significant at $\mathrm{p}<0.05$ and $\mathrm{p}<0.01$ respectively; ns: not significant.

The increasing $\mathrm{NaCl}$ application decreased root, stem, and leaf dry matter. The decreasing effect of salt on root dry weight was higher than for the stem and leaf dry weights. The interaction of $\mathrm{P} \times \mathrm{S}$ showed the highest dry weight of root $(0.531 \mathrm{~g})$, stem $(0.354 \mathrm{~g})$ and leaf $(1.010 \mathrm{~g})$ at $\mathrm{P}_{90}$ under non-saline condition (Figure 1). The lowest dry weight of root $(0.321 \mathrm{~g}$ with a $27 \%$ decrease compared to control) and leaf $(0.654 \mathrm{~g}$ with a $22 \%$ decrease compared to control) was determined by $150 \mathrm{mM} \mathrm{NaCl}$ application, while stem $(0.241 \mathrm{~g}$ with a $23 \%$ decrease compared to control) was 
obtained the highest dry weight by $50 \mathrm{mM} \mathrm{NaCl}$ (Table 1). These results were in agreement with studies on salinity (Shahriaripour et al., 2011; Weisany et al., 2014) that stated that $\mathrm{NaCl}$ application decreased the dry weight of crops. The growth of crop species and cultivars shows the different responses to salinity. Green beans are sensitive to salt stress and it has been reported that dry weights of bean varieties were decreased with increased $\mathrm{NaCl}$ concentrations in irrigation water (Gulmezoglu et al., 2016). A decrease in the usable water amount causes the cell expansion to diminish (Dadkhah and Grrifiths, 2006). Reduction in dry weight of the root and vegetative parts under salt stress may be osmotic stress due to decreasing transpiration and lack of nutrition. Abbas et al. (2014) showed that the leaves of the crop might be smaller and thicker under a salt condition, to reduce water loss by evaporation from their surface.

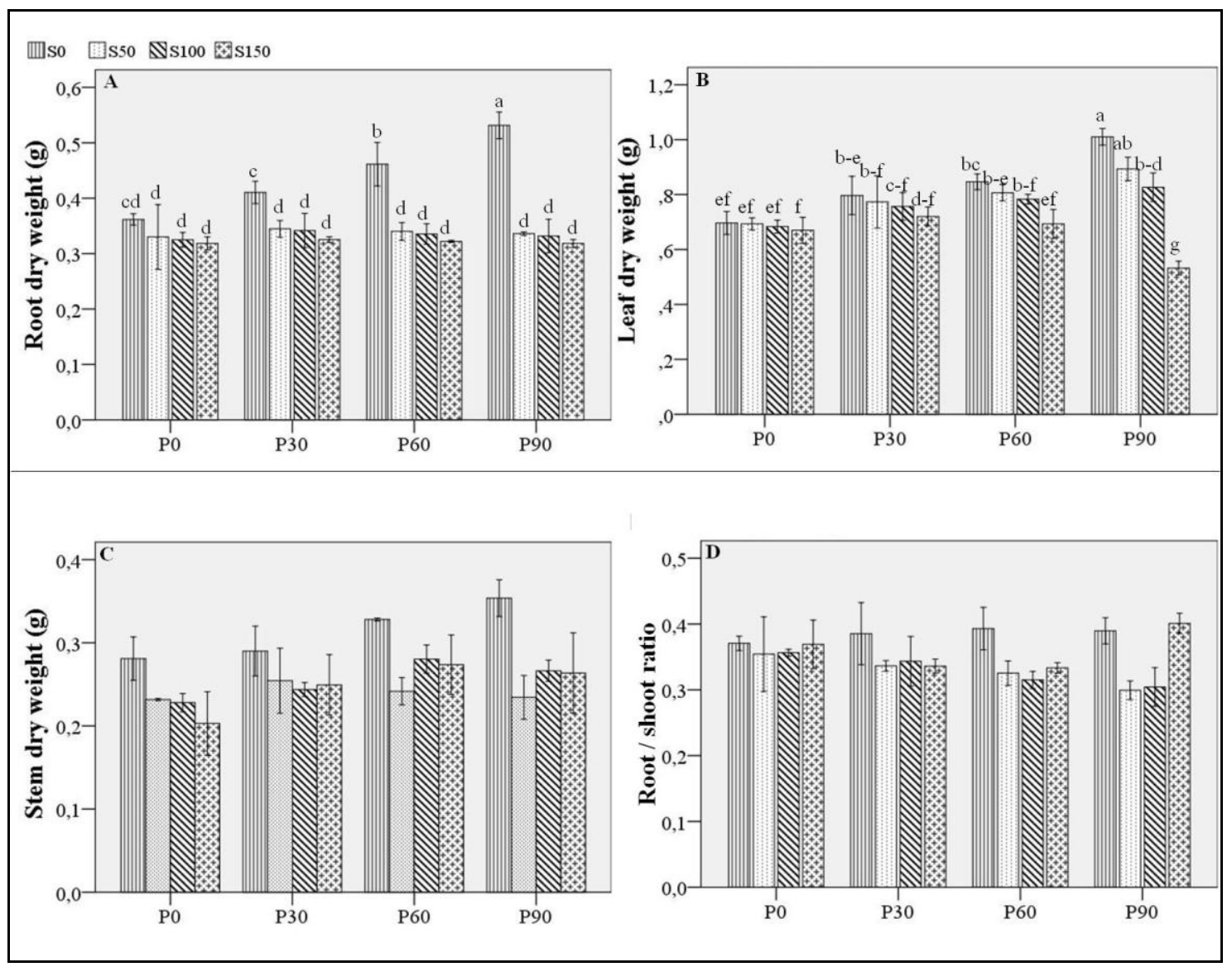

Figure 1. The interaction values of phosphorus and $\mathrm{NaCl}$ treatments on dry weight of root (A), leaf $(B)$, stem $(C)$ and root/shoot ratio $(D)$ of green bean plants

The $\mathrm{R} / \mathrm{S}$ ratio was significantly $(\mathrm{p}<0.05)$ effected by $\mathrm{NaCl}$ application (Table 1; Figure 1). On the other hand, $\mathrm{P}$ and $\mathrm{P} \times \mathrm{S}$ interaction effects were significant and the $\mathrm{R} / \mathrm{S}$ ratio was decreased with the $\mathrm{P}$ application compared to control. It was found that a $150 \mathrm{mM} \mathrm{NaCl}$ dose increased the R/S ratio much more than 50 and $100 \mathrm{mM} \mathrm{NaCl}$ doses, but the $\mathrm{R} / \mathrm{S}$ ratio was the highest at the no- $\mathrm{NaCl}$ condition (0.385) (Figure 1c). In the present study, the highest R/S ratio (0.401) was determined by the application of $150 \mathrm{~mm} \mathrm{NaCl}$ at the $\mathrm{P}_{90}$ rate. Allocation of plant dry weight to roots in seedlings was greater when grown in the highest $\mathrm{NaCl}$ doses rather than in dilutions of $\mathrm{NaCl}$ because 
shoot dry matter production was decreased under high salt stress. These decreases in the $\mathrm{R} / \mathrm{S}$ ratio by salt stress varied from $6 \%$ to $15 \%$ (Table 1 ). This view suggests that the variation in growth was controlled by the effects of salinity on root growth, which include the lack of adequate nutrients in the growing environment. Sufficient P makes efforts to increase dry matter accumulation by increasing the photosynthesis product of root and shoot. Whereas inadequate supply of $\mathrm{P}$ restricts leaf expansion and slows the growth of the plant by reducing the water transmission of the root system. The root growth is much less affected than shoot growth under $\mathrm{P}$ deficiency so that the deficient $\mathrm{P}$ in plants is generally high in R/S ratio (Raghothama 1999; Talbi-Zribi et al. 2014). This high rate concerns the preferential division of carbohydrates into the roots (Cakmak et al, 1994).

\section{Phosphorus concentration of plant}

The variance analysis showed that $\mathrm{P}$ and salinity had a significant effect on $\mathrm{P}$ concentration in the root $(\mathrm{p}<0.05)$ and stem and leaf $(\mathrm{p}<0.01)$ of green beans (Table 1; Figure 2). But there was only significant effect on the $\mathrm{P} \times \mathrm{S}$ interaction of the leaf $(\mathrm{p}<0.05)$. The $\mathrm{P}$ concentration of plant parts was increased with $\mathrm{P}$ application in comparison to control. The highest $\mathrm{P}$ concentration was obtained in the root $(0.397 \%)$, leaf $(0.248 \%)$ and stem $(0.203 \%)$, respectively, at $\mathrm{P}_{90}$ treatment.

Salinity decreased $\mathrm{P}$ concentration of plant parts (Table 1; Figure 2). The lowest $\mathrm{P}$ concentrations were recorded in stem $(0.161 \%)$ with the control treatment, and in leaves $(0.209 \%)$ and roots $(0.361 \%)$ with $150 \mathrm{mM} \mathrm{NaCl}$ treatments. The treatment of $50 \mathrm{mM} \mathrm{NaCl}$ had the increased the $\mathrm{P}$ concentration of plant parts (Figure 2). The $\mathrm{P}$ accumulation of plant parts under the $\mathrm{P}$ and $\mathrm{NaCl}$ treatments were as follows: stem<leaf<root. A similar result was reported by Shahriaripour et al. (2011), who investigated the effect of increasing treatment of $\mathrm{P}$ and salinity on pistachio seedlings grown in a calcareous soil under greenhouse conditions. They found that $\mathrm{NaCl}$ decreased leaf, stem, and root $\mathrm{P}$ concentrations, but $\mathrm{P}$ treatments increased $\mathrm{P}$ concentrations in the leaf, stem, and root of the bean plant.

The significant interaction of $\mathrm{P} \times \mathrm{NaCl}$ on the leaves was determined by $\mathrm{P}_{60}$ with 50 $\mathrm{mM} \mathrm{NaCl}$. Generally, vacuoles are a storage for P in leaves; nevertheless, P mobility is reduced in high salt existence (Bargaz et al., 2016). Indeed, one possible explanation for the increase of $\mathrm{P}$ concentration is that $\mathrm{NaCl}$ at low or moderate levels stimulates the $\mathrm{P}$ uptake of the bean. This result was coherent with the findings of Rubio et al. (2005), who determined a Na-dependent high affinity phosphate transporter in the plasma membrane of root and leaf cells of Zostera marina L. Similarly, Talbi-Zribi et al. (2012) showed that mild salinity could mitigate the negative effects of $\mathrm{P}$ deficiency in plant photosynthesis activity for barley. However, a reverse effect reported by Grattan and Grieve (1999) was that salinity could decrease P uptake and the interaction of salinity and $\mathrm{P}$ availability is depend on the development stage and species of plant. Our findings suggested that $\mathrm{P}$ concentration in bean leaves was affected positively by mild $\mathrm{NaCl}$ doses. 


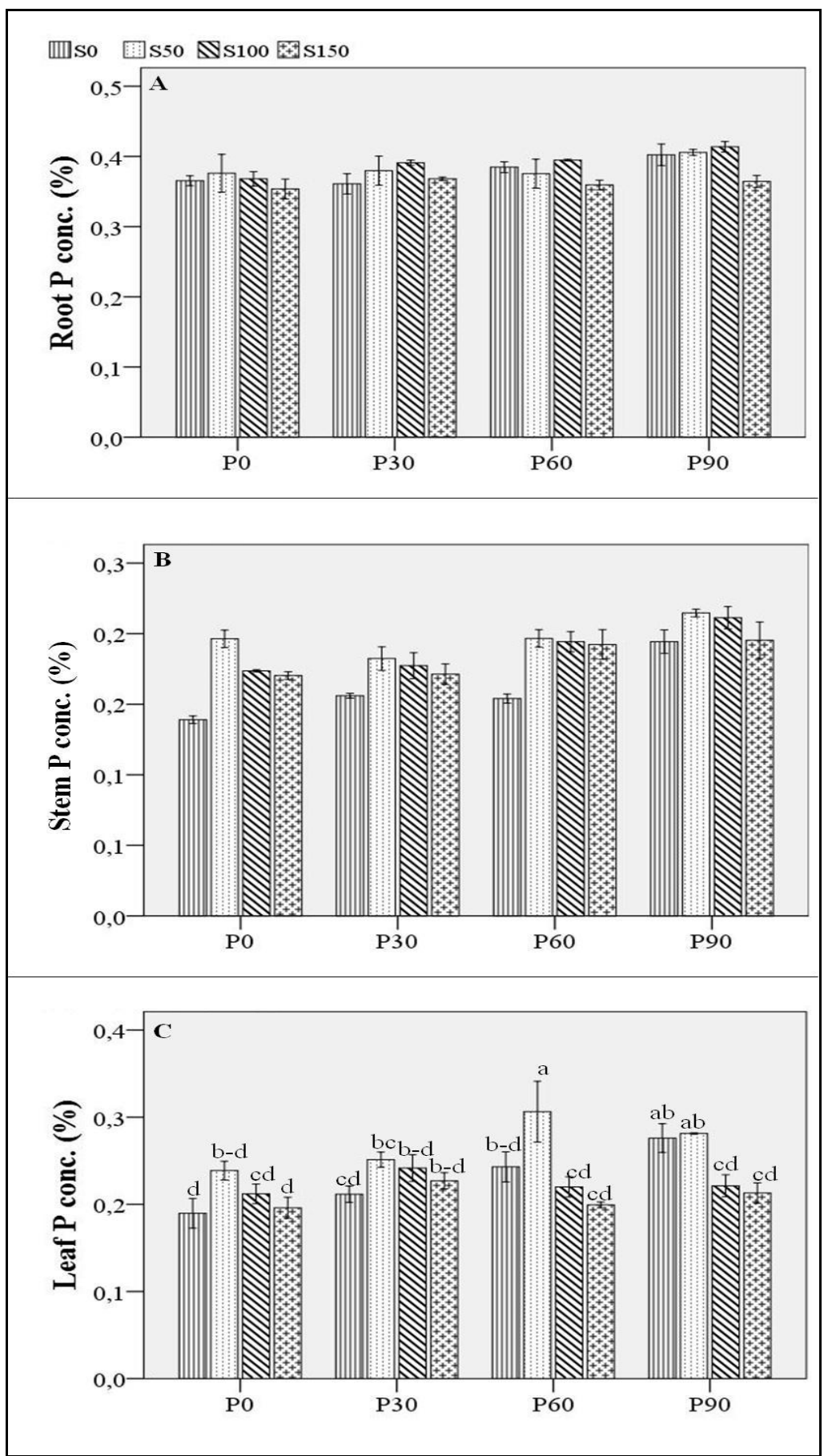

Figure 2. The phosphorus concentration (\%) in root (A), stem, and leaf of green beans under salinity and phosphorus treatments

\section{Chlorophyll content}

Increasing $\mathrm{P}$ treatment increased young leaf chlorophyll content, and this was significant $(\mathrm{p}<0.01)$ (Table 2; Figure 3). The highest chlorophyll content in young leaves was obtained from the $\mathrm{P}_{60}$ dose. The old leaf chlorophyll content was higher than that of young leaves, but $\mathrm{P}$ treatments did not significantly affect the old leaf chlorophyll contents. 


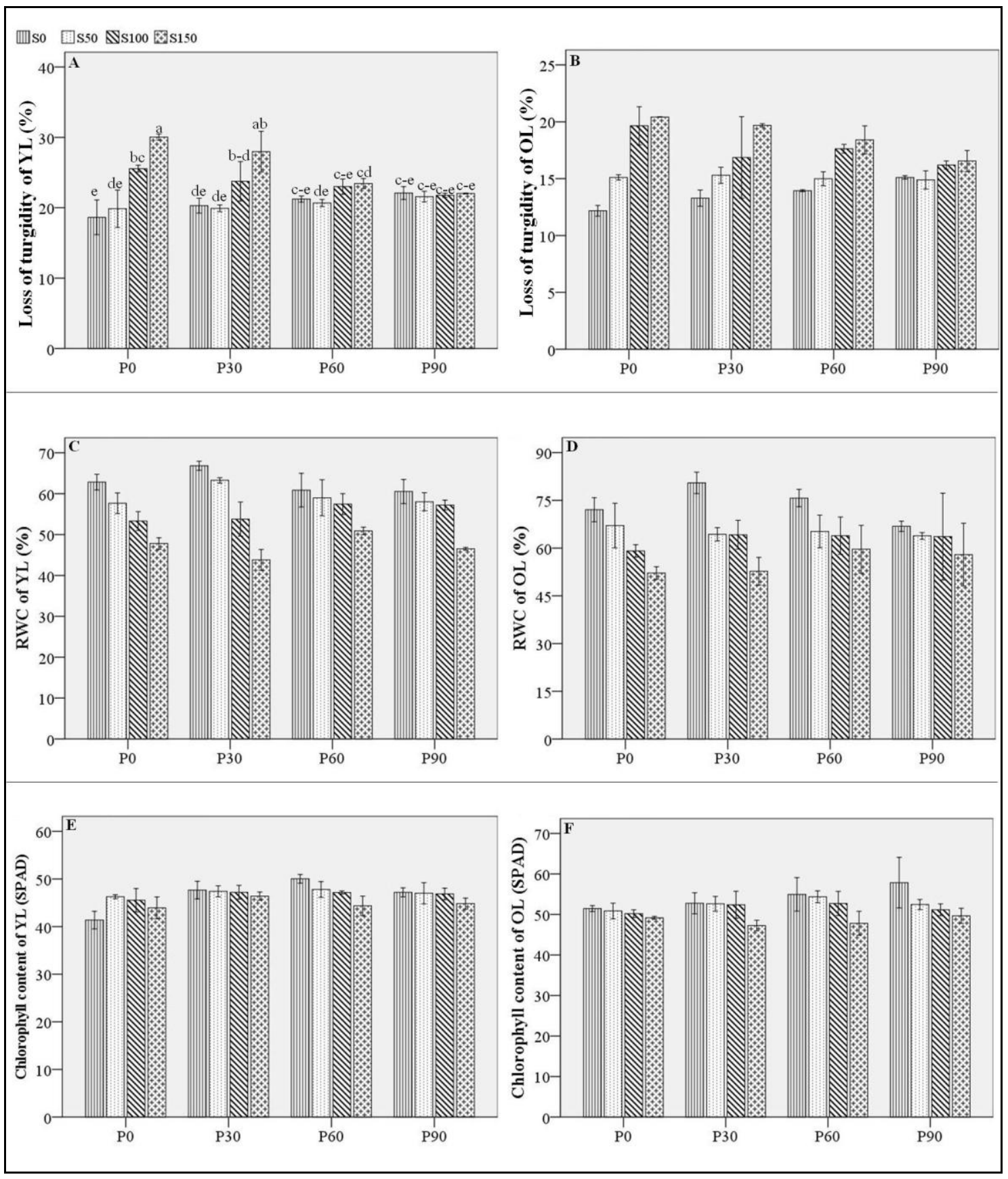

Figure 3. The effect of phosphorus and $\mathrm{NaCl}$ treatments on loss of turgidity (A: young leaf; $\mathrm{B}$ : old leaf), leaf relative water content (A: young leaf; B: old leaf), and chlorophyll content (A: young leaf; B: old leaf) of green beans

Salt treatment did not affect young leaf chlorophyll content, but the effect of $\mathrm{NaCl}$ treatments on old leaf chlorophyll content was significantly important $(p<0.01)$. The chlorophyll content of old leaves was decreased with $\mathrm{NaCl}$ treatments, with the lowest chlorophyll content (48.48 SPAD unit) measured at $150 \mathrm{mM} \mathrm{NaCl}$ treatments. Sodium concentration increases in leaves under salt stress, which increases oxidative stress. The increased oxidative stress leads to chlorophyll loss and consequently overall decrease of chlorophyll content. Nevertheless, $\mathrm{Na}$ is required for carbon metabolism and for 
chlorophyll synthesis in some $\mathrm{C} 4$ plants. The decrease of chlorophyll content under $\mathrm{NaCl}$ stress was found by Khosravinejad et al. (2008) and Talbi-Zribi et al. (2012). The effect of P x S interaction on the chlorophyll content of either young or old leaves was not found significant in this study.

Table 2. The effects of $P$ and $\mathrm{NaCl}$ treatments on chlorophyll, loss of turgidity and leaf relative water content of green bean

\begin{tabular}{|c|c|c|c|c|c|c|}
\hline \multirow{2}{*}{ Treatment } & \multicolumn{2}{|c|}{$\begin{array}{l}\text { Chlorophyll } \\
\text { (SPAD unit) }\end{array}$} & \multicolumn{2}{|c|}{$\begin{array}{c}\text { Loss of Turgidity } \\
(\%)\end{array}$} & \multicolumn{2}{|c|}{$\begin{array}{c}\text { Leaf RWC } \\
(\%)\end{array}$} \\
\hline & $\begin{array}{l}\text { Young } \\
\text { Leaves }\end{array}$ & $\begin{array}{c}\text { Old } \\
\text { Leaves }\end{array}$ & $\begin{array}{l}\text { Young } \\
\text { Leaves }\end{array}$ & $\begin{array}{c}\text { Old } \\
\text { Leaves }\end{array}$ & $\begin{array}{l}\text { Young } \\
\text { Leaves }\end{array}$ & $\begin{array}{c}\text { Old } \\
\text { Leaves }\end{array}$ \\
\hline $\mathrm{P}_{0}$ & $44.27 \mathrm{~b}$ & 50.42 & 23.52 & 15.11 & 55.41 & 62.60 \\
\hline $\mathrm{P}_{30}$ & $47.08 \mathrm{a}$ & 51.26 & 22.99 & 16.28 & 56.68 & 65.44 \\
\hline $\mathrm{P}_{60}$ & $47.34 \mathrm{a}$ & 52.47 & 22.09 & 16.24 & 57.06 & 66.13 \\
\hline $\mathrm{P}_{90}$ & $46.47 \mathrm{a}$ & 52.79 & 21.87 & 15.69 & 55.57 & 63.06 \\
\hline$L S D_{0.05}$ & 1.743 & 3.272 & 2.194 & 1.562 & 3.717 & 7.950 \\
\hline $\mathrm{S}_{0}$ & 46.56 & $54.26 \mathrm{a}$ & $20.56 c$ & $13.63 b$ & $62.76 a$ & $73.79 a$ \\
\hline $\mathrm{S}_{50}$ & 47.11 & $52.58 \mathrm{a}$ & $20.50 \mathrm{c}$ & $15.07 \mathrm{~b}$ & $59.49 a$ & $65.12 b$ \\
\hline$S_{100}$ & 46.69 & $51.62 \mathrm{ab}$ & $23.51 b$ & $17.58 \mathrm{a}$ & $55.44 b$ & $62.70 b c$ \\
\hline $\mathrm{S}_{150}$ & 44.88 & $48.48 \mathrm{~b}$ & $25.87 \mathrm{a}$ & $18.77 \mathrm{a}$ & $47.25 \mathrm{c}$ & $55.62 \mathrm{c}$ \\
\hline$L S D_{0.05}$ & 1.743 & 3.272 & 2.194 & 1.562 & 3.717 & 7.950 \\
\hline$P$ & $* *$ & $\mathrm{~ns}$ & $\mathrm{~ns}$ & $\mathrm{~ns}$ & $\mathrm{~ns}$ & $\mathrm{~ns}$ \\
\hline$S$ & $\mathrm{~ns}$ & $* *$ & $* *$ & $* *$ & $* *$ & $* *$ \\
\hline$P \times S$ & $\mathrm{~ns}$ & $\mathrm{~ns}$ & $*$ & ns & ns & $\mathrm{ns}$ \\
\hline
\end{tabular}

\section{Loss of turgidity}

The effects of $\mathrm{P}$ treatment on leaves of both ages were not significant (Table 2). The highest loss of turgidity (23.52\%) was obtained in young leaves without P treatment. Increased $\mathrm{P}$ doses decreased loss of turgidity in young leaves partially compared to control; however, it was not determined from old leaves (Figure 3). The loss of turgidity in both young and old leaves was increased by salinity (Table 2). Although the effect of salt treatments on the loss of turgidity of both leaves was found significantly $(\mathrm{p}<0.01)$, the interaction of $\mathrm{P} \times \mathrm{S}(\mathrm{p}<0.05)$ on the loss of turgidity was significant only in young leaves. The $\mathrm{P}_{0}$ with $150 \mathrm{mM} \mathrm{NaCl}$ application had the highest loss of turgidity in younger leaves (30.0\%) (Figure 3). The loss of turgidity of the young leaves was higher than the old leaves in this study, as the reduction of water potential is greater in young leaves than older leaves. This result could be explained as the water potential in young leaves linearly depending on the increase of the salt concentration. The wilting of flowers and leaves due to loss of water from plant cells was caused by the loss of turgidity (Dadkhah and Grrifiths, 2006). Salt stress occurs in plants with an excess of dissolved salts in the root area, a low osmotic potential, a high concentration of toxic ions, or a combination of these factors. Plants under salt stress are observed first with wilting symptoms, then growth inhibition and yield loss (Shahriaripour et al., 2011; 
Parvaiz and Satyawati, 2008). Due to declining water uptake by the plant, water transports less to the younger leaves under the salt stress; however, our results indicated that plants' water use increased with decreasing loss of turgidity in young leaves, depending on $\mathrm{P}$ treatments.

\section{Leaf relative water content capacity}

The leaf relative water content of younger and older leaves was significantly affected only with $\mathrm{NaCl}$ application $(\mathrm{p}<0.01)$ (Table 2). Further, increased salt strongly reduced leaf water potential in young leaves more than in older leaves (Figure 3). Water status is a major factor affecting plant growth and development. A decrease of the leaf relative water content under saline conditions has been observed frequently (Qin et al., 2010; Aroca et al., 2012). The decrease of water uptake under salt stress conditions could be a strategy to diminish the water flow from the roots to the soil while the soil osmotic potential is lower than that of the roots. Reducing the external water potential with salinity decreases the cell osmotic potential required for the turgor press (Munns, 2002). This indicates that the low rate of water uptake after salt application is responsible for the low transpiration rate, and also that salinity results in dehydration at the cellular level; symptoms of dehydration were higher in the higher $\mathrm{NaCl}$ applications due to increased cellular water loss.

In conclusion, the evaluation of the effects of $\mathrm{P}$ and $\mathrm{NaCl}$ on the growth performances and the water loss and capacity of green beans showed that $\mathrm{P}$ treatments significantly increased the dry weight and $\mathrm{P}$ concentrations of plant parts and the chlorophyll content of young leaves. All of the parameters except the chlorophyll content of young leaves were affected by salinity. Dry matters of plant parts as well as the leaf relative water content of younger and older leaves were decreased, but the loss of turgidity of younger and older leaves was increased with higher $\mathrm{NaCl}$ applications when compared to control. However, $\mathrm{P}_{60}$ with $50 \mathrm{mM} \mathrm{NaCl}$ was found to have the effect of increasing leaf $\mathrm{P}$ concentration and decreasing the loss of turgidity in younger leaves, which could suggest that a moderate level of $\mathrm{P}$ application may contribute to the water potential of green beans under salinization.

\section{REFERENCES}

[1] Abbas, F., Al-Jbawi, E., Ibrahim, M. (2014): Growth and chlorophyll fluorescence under salinity stress in sugar beet (Beta vulgaris L.). - International Journal of Environment 3(1): 1-9, DOI: http://dx.doi.org/10.3126/ije.v3i1.9937.

[2] Adhami, A., Ronaghi, A. (1999): Effect P and $\mathrm{Zn}$ on growth and chemical content in corn, bean, soybean and faba bean. - In: Proceeding of 6th Congress of Soil Science. University of Mashhad, Ferdowsi.

[3] Aroca, R., Porcel, R., Ruiz-Lozano, J.M. (2012): Regulation of root water uptake under abiotic stress conditions. - Journal of Experimental Botany 63(1): 43-57.

[4] Bargaz, A., Nassar, R.M.A., Rady, M.M., Gaballah, M.S., Thompson, S.M., Brestic, M., Abdelhamid, M.T. (2016): Improved salinity tolerance by phosphorus fertilizer in two Phaseolus vulgaris recombinant inbred lines contrasting in their P-efficiency. - Journal of Agronomy and Crop Science 202(6): 497-507.

[5] Barrs, H. D., Weatherley, P.E. (1962): A re-examination of the relative turgidity technique for estimating water deficits in leaves. - Australian Journal of Biological Sciences 15(3): 413-428. 
[6] Barton, C.J. (1948): Photometric analysis of phosphate rocks. - Analytical Chemistry 20: 1068-1073.

[7] Bouyoucos, G.J. (1962): Hydrometer method improved for making particle size analysis of soils. - Agronomy Journal 54: 464-465.

[8] Cakmak, I., Hengeler, C., Marschner, H. (1994): Partitioning of shoot and root dry matter and carbohydrates in bean plants suffering from phosphorus, potassium and magnesium deficiency. - Journal of Experimental Botany 45(9): 1245-1250.

[9] Dadkhah, A.R., Grifiths, H. (2006): The Effect of Salinity on Growth, Inorganic Ions and Dry Matter Partitioning in Sugar Beet Cultivars. - Journal of Agricultural Science and Technology 8: 199-210.

[10] Fageria, N.K., De Carvalho, A.M. (1996): Response of common bean to phosphorus on acid soils. - Communications in Soil Science and Plant Analysis 27(5-8): 1447-1458.

[11] FAOStat. (2013): Agriculture Organization of the United Nations, 2013. FAO, Retrieved from http://faostat3. fao. org/faostat-gateway/go/to/download/Q/QC/S. Acceso, 20.

[12] Gidago, G., Beyene, S., Worku, W., Sodo, E. (2011): The response of haricot bean (Phaseolus vulgaris L.) to phosphorus application on Ultisols at Areka, Southern Ethiopia. - Journal of Biology, Agriculture and Healthcare 1(3): 38-49.

[13] Grattan, S.R., Grieve, C.M. (1999): Salinity mineral nutrient relations in horticultural crops. - Scientia Horticulturae 78: 127-157.

[14] Gulmezoglu, N., Aydogan, C., Turhan, E. (2016): Physiological, biochemical and mineral dimensions of green bean genotypes depending on $\mathrm{Zn}$ priming and salinity. - Legume Research 39(5): 713-721.

[15] Jamil, A., Riaz, S., Ashraf, M., Foolad, M.R. (2011): Gene expression profiling of plants under salt stress. - Critical Reviews in Plant Sciences 30(5): 435-458.

[16] Johnston, A.E., Steén, I. (2000): Understanding phosphorus and its use in agriculture. European Fertilizer Manufacturers' Association. http://www.fertilizerseurope.com/fileadmin/user_upload/publications/agriculture_publica tions/EFMA_Phosphorus_booklet_2_.pdf (Internet: 29.03.2017).

[17] Kachout, S., Mansoura, A.B., Jaffel, K., Leclerc, J.C., Rejeb, M.N., Ouerghi, Z. (2009): The effect of salinity on the growth of the halophyte Atriplex hortensis (Chenopodiaceae). - Applied Ecology and Environmental Research 7(4): 319-332.

[18] Khosravinejad F., Heydari R., Farboodnia T. (2008): Effects of salinity on photosynthetic pigments, respiration, and water content in two barley varieties. - Pakistan Journal of Biological Sciences 11: 2438-2442.

[19] Kouas, S., Labidi, N., Debez, A., Abdelly, C. (2005): Effect of P on nodule formation and N fixation in bean. - Agronomy for Sustainable Development 25(3): 389-393.

[20] Lindsay, W.L., Norvell, W.A. (1978): Development of a DTPA test for zinc, iron, manganese, and copper. - Soil Science Society of America Journal 42 421-428.

[21] Munns, R. (2002): Comparative physiology of salt and water stress. - Plant, Cell \& Environment 25(2): 239-250.

[22] Nelson, D.W., Sommers, L.E. (1996): Total carbon, organic carbon, and organic matter. In: Bigham J.M. (ed) Methods of Soil Analysis. Part 3. Chemical methods. Madison: Soil Science Society of America and American Society of Agronomy 9: 961-1010.

[23] Olsen, S.R., Cole, C.V., Watanabe, F.S., Dean, L.A. (1954): Estimation of available phosphorus in soils by extraction with sodium bicarbonate. - US Department of Agriculture Circular No:939, US Government Printing Office, Washington pp.1-19.

[24] Parida, A.K., Das, A.B. (2005): Salt tolerance and salinity effect on plants: a review. Ecotoxicology and Environmental Safety 60: 324-349.

[25] Parvaiz, A., Satyawati, S. (2008): Salt stress and phyto-biochemical responses of plants- a review. - Plant Soil Environment 54(3): 89-99.

[26] Qin, J., Dong, W., He, K.N., Yu, Y., Tan, G.D., Han, L., Dong, M., Zhang, Y.Y., Zhang, D., Li, A.Z., Wang, Z.L. (2010): $\mathrm{NaCl}$ salinity-induced changes in water status, ion 
contents and photosynthetic properties of Shepherdia argentea (Pursh) Nutt. seedlings. Plant, Soil and Environment 56(7): 325-332.

[27] Rafat, M., Sharifi, P. (2015): The effect of phosphorus on yield and yield components of green bean. - Journal of Soil Nature 8(1): 9-13.

[28] Raghothama, K.G. (1999): Phosphate acquisition. - Annual Review of Plant Physiology and Plant Molecular Biology 50: 665-693.

[29] Richards, L.A. (1954): Diagnosis and improvement of saline and alkali soils Agricultural hand book 60. - U.S. Dept. of Agriculture, Washington D.C., 160 p.

[30] Rubio, L., Linares-Rueda, A., García-Sánchez, M. J., Fernández, J.A. (2005): Physiological evidence for a sodium-dependent high-affinity phosphate and nitrate transport at the plasma membrane of leaf and root cells of Zostera marina L. - Journal of Experimental Botany 56(412): 613-622.

[31] Shahriaripour, R., Tajabadi Pour, A., Mozaffari, V. (2011): Effects of Salinity and Soil Phosphorus Application on Growth and Chemical Composition of Pistachio Seedlings. Communications in Soil Science and Plant Analysis 42(2): 144-158.

[32] Talbi-Zribi, O., Labidi, N., Slama, I., Debez, A., Ksouri, R., Rabhi, M., Smaoui, A., Abdelly, C. (2012): Alleviation of phosphorus deficiency stress by moderate salinity in the halophyte Hordeum maritimum L. - Plant Growth Regulation 66: 75-85.

[33] Talbi-Zribi, O., Houmani, H., Kouas, S., Slama, I., Ksouri, R., Abdelly, C. (2014): Comparative study of the interactive effects of salinity and phosphorus availability in wild (Hordeum maritimum) and cultivated carley (H. vulgare). - Journal of Plant Growth Regulation (33): 860-870.

[34] Tuteja, N. (2007): Mechanisms of high salinity tolerance in plants. - Methods in Enzymology 428: 419-438.

[35] Yamasaki, S., Dillenburg, L.C. (1999): Measurements of Leaf Relative Water Content in Araucaria angustifolia. - The Revista Brasileira de Fisiologia Vegetal (Brazilian Journal of Plant Physiology) 11: 69-75.

[36] Weisany, W., Sohrabi, Y., Heidari, G., Siosemardeh, A., Badakhshan, H. (2014): Effects of zinc application on growth, absorption and distribution of mineral nutrients under salinity stress in soybean (Glycine max L.). - Journal of Plant Nutrition 37(14): 22552269. 